\title{
ANGLO-AMERICAN SCHOOLS OF SCIENTIFIC COMMUNICATION IN THE CONTEXT OF ACADEMIC DISCOURSE GENRES
}

\author{
Svitlana Shcherbyna \\ Dragomanov National Pedagogical University, Kyiv, Ukraine \\ sveta.sh@i.ua
}

\begin{abstract}
The article presents a critical review of research works dedicated to Anglo-American scientific communication debates on academic discourse genres. This study shows that Standard English represented by British English and American English dominates in AngloAmerican scientific communication. It has been assumed that Anglo-American academic discourse, as a scientific notion of discourse study is a hybrid term used to identify two interrelated types of discourse: instructional-pedagogical discourse that comprises teaching and learning practices in educational establishment and research-oriented discourse relating to research data sharing between different discourse communities. The results of the present study have revealed the internal genre taxonomy of AngloAmerican research-oriented discourse identified by criterion academic spoken or written communication, with spoken research genres further divided into research report, conference presentation, roundtable discussions, dissertation defence and written research genres divided into research article, monograph, dissertation, abstract, and summary. The research article is claimed to be the leading research genre recognised by a distinct rhetorical structure: Introduction, Method, Results, Discussion and Conclusions. Finally, three main approaches to genre analysis introduced by Anglo-American scientific communication schools have been overviewed, namely neo-rhetorical (North American New Rhetoric Studies), sociocultural (Australian systematic functional linguistics) and linguodidactic approach (English for Specific Purposes).
\end{abstract}

Keywords: Anglo-American scientific communication; academic discourse; academic discourse genres; discourse community; academic spoken and written communication.

\section{Introduction}

Modern Science of the $21^{\text {st }}$ century has not just become international in terms of the world information processes aimed at establishing worldwide contacts between scientists and researchers, but it has acquired the status of being Global and Cross-Cultural. These processes have become primarily beneficial to scholars and researchers all over the world able to obtain the latest information in different fields and communicate with their colleagues throughout the world. At present, we observe the intense growth of international scientific cooperation, which is impossible without English as a lingua franca represented by a number of varieties, namely Standard English, International English, New Englishes, and World Englishes.

We assume that the appearance of these variants is the result of linguogeographical peculiarities of the English language. According to the Japanese scientist Kachru (1992), the rapid growth of English can be described in terms of three concentric circles: the Inner Circle, the Outer Circle and the Expanding Circle (p. 48-74). The Inner circle refers to native speakers from the USA, the UK, Canada, Australia and New Zealand. The representatives of this circle use typical communicative samples (Kapranov, 2018). The Outer Circle comprises non-native settings represented by former colonies of the UK or the USA, where the English language plays a 'second language' role). The Expanding Circle includes those who use English as a foreign language (Kachru, 1992, p. 48-74).

\section{Method}

Standard English represented by two national variants of English - British (British English) and American (American English) dominates in Anglo-American scientific communication. It reflects typical communicative sample of the native speakers (representatives of the Inner Circle). According to Ilchenko (2013), "today it is a question of universal standards in Anglo-American academic discourse, since the vast majority of publishing houses in the world are British-American or such which are guided by the specified standards" (p. 327).

But is the notion "academic discourse" widely used by native speakers - experts in the field of scientific communication? And if so, what meaning do they put in this concept? To find an answer to this question, as well as to analyse the concept of Anglo-American academic discourse within the scope of linguogeneology, the following methods have been used: the method of analysis and synthesis, the method of genre discourse analysis, the notions taxonomy method, and the interpretation method. In particular, with the help of the method of analysis and synthesis, we came to the conclusion that Western and Anglo-American linguistic traditions operate the notion "academic discourse" (e.g. Becher, 2001; Hyland, 2011; Ferris, 1998; Swales, 2004), which is defined as "the process of intellectual and communicative interaction of academic community members within an educational institution, implemented in social activities like educating students, demonstrating learning, disseminating ideas and constructing knowledge, rely on language to 
accomplish" (Hyland, 2009, p. 25). Applying to the notions taxonomy method and discourse analysis, it has been found out that academic discourse is characterised by social context, as it "determines social roles and forms of verbally indirect interaction between different discourse communities in the process of research data sharing" (Hyland, 2009, pp. 28-32). Applying to interpretation method, British scholar Ken Hyland has revealed that academic discourse is the result of three major developments over the past 20 years. They are the following: 1) the changes in higher education, which have resulted in greater interest given to the importance of academic writing; 2) the growth of English as the international language of research; 3) the emergence of theoretical perspectives, which recognise the centrality of academic discourses in the construction of knowledge (Hyland, 2011, p. 172).

\section{The criteria of Anglo-American academic discourse genre taxonomy}

Academic discourse is analysed from two different perspectives. On the one hand, academic discourse serves as an instructional-pedagogical discourse that comprises teaching and learning practices in educational establishment. On the other hand, academic discourse is a research-oriented discourse relevant to research data sharing between different discourse communities (Bellés-Fortuño, 2010, p. 907). The correlations between these two perspectives of academic discourse result in their genre taxonomy.

In general, foreign linguists define genres as different categories of texts in relation to a particular type of discourse depending on the use of language in specialised register (Perez-Llatanda Auria, 2001, p. 252). The content of a research paper is cohesive and subordinates the semantic structure of a definite research genre (White, 2006, p.189).

Fortanet (2005) distinguishes three levels of academic spoken genres: classroom, institutional and research genres. Classroom genres have a clear pedagogical-instructional aim (e.g. lecture, seminar, tutorial, interview, students' presentation, and exam). Institutional genres defined as ceremonial genres are close to research genres in terms of communicative purpose (e.g. academic year opening lecture, commencement address, prize acceptance speech). Research genres include conference genres - plenary lecture, paper presentation, poster presentation, colloquium, seminar, research meeting and other research-oriented genres used for presenting the scientific research results (e.g. $\mathrm{PhD}$ thesis defence, research project, master thesis) (Fortanet, 2005, pp. 3-51).

The presented genre taxonomy gives the grounds to consider academic discourse as a hybrid type of discourse defined through two interrelated types of discourse: instructional-pedagogical academic discourse and research-oriented academic discourse.

The internal academic discourse genre taxonomy is defined by criterion of academic spoken/written communication. According to Brookes and Grundy (1990), this taxonomy includes spoken research genres divided into research report, conference presentation, roundtable discussions, dissertation defence and written research genres divided into research article, monograph, dissertation, abstract, and summary (p. 162).

The communicative purpose of research-oriented academic discourse predicts research data sharing between different discourse communities focused on definite set of genres. Swales (1990) introduced the notion "discourse community" to identify the members of academic and research settings. Discourse community is a "group of people that has common goals or purposes, and use communication to achieve these goals" (Swales, 1990, pp. 24-27). Moreover, Swales (1990) defined six main characteristics of discourse community: 1) an agreed set of common tasks and goals; 2) developed mechanisms of communication among the members of discourse community (e.g. telecommunication, correspondence); 3) access to information (e.g. academic journal subscription); 4) possession of one or more genres; 5) knowledge of lexis (community-specific abbreviations and acronyms); 6) a threshold level of members with a suitable degree of relevant content (Swales, 1990, pp. 24-27).

\section{Anglo-American schools' approaches to genre analysis}

At present, Anglo-American linguogeneology is represented by three approachers: new rhetorical (North American New Rhetoric Studies), sociocultural (Australian systematic functional linguistics), and linguodidactic (the theory of the genre within the concept of the English language for special purposes (English for Specific Purposes - ESP) and corpus linguistics.

\subsection{The 'New Rhetoric' School approach}

Representatives of the North American School of New Rhetoric (e.g. Bathia, 2008; Bazerman, 1997; Miller, 1984; Swales, 2004) focused on studying the registers of communication by analysing discourse and differentiating verbal and written speech in their genre varieties. 
The greatest contribution of this school belongs to Swales (1990) who developed the concept of socalled "applied genre analysis", that is the typological interpretation of text content taking into account socio-communicative specificity and provides a description of the communicative goals of the text by categorising various discursive components by their communicative functions, also known as "rhetorical moves". The structure of rhetorical moves shows the communicative purposes of the structural parts of texts in their genre varieties. Rhetorical moves consist of "rhetorical steps" (Swales, 2004, p. 228).

In this sense a genre is a class of communicative events, the members of which share some set of communicative purposes with variations/deviations from the prototype models of certain genres, dependence of content and forms of text implementation from the genre purpose and recognition of the leading role of members of discourse communities in the development of genres (Swales, 1990, p. 58). The scholar identified five main genre characteristics: 1) the status of communicative event; 2) a set of communicative purposes; 3) structural-context similarity; 4) variability/dynamism; 5) instrument of discourse community (Swales, 1990, p. 58). This characteristic follows the main feature of the genre, which is associated with the allocation of the intended purpose of the genre, since the purpose of the genre determines the structure of the text and the choice of verbal and rhetorical strategies. This is also noted by the authors of the monograph "Theory of the genre: theoretical and applied aspects" (Korneiko, Petrova, Popov, 2014, p. 36).

In Swales's opinion, the leading genre of Anglo-American scientific communication is a research article characterised by logical and clear structure, the so-called "rhetorical structure", which comprises a set of structural elements, namely Introduction, Methods, Results, Discussion and Conclusions (Swales, 2004, pp. 13-16).

Swales \& Feak (2004) presented a generalised model of the introductory part of a research article socalled "Create a Research Space Model". This name corresponds to the communicative and pragmatic goals of the introductory part: to substantiate the importance of research in a certain area of activity for the discourse community. Swales (1990) presented the introduction to English-language research articles in the form of successive rhetorical moves, namely: 1) establishing a territory (defining the problem of research) by implying the importance of this study and/or review of previous studies); 2) the definition of a specific scientific task/scientific problem which the author of the article intends to solve (by choosing one of the strategies: identifying unsolved issues in a particular field in previous research; scientific counterargumentation; formulation of a research question or continuation of existing research); 3) implementation of this task (occupying the niche) (outlining the purpose of the article or generalising its main results. Swales's model has become a specimen used for further development of methods of analysis in relation to the rhetorical structure of genres in different fields of knowledge.

His follower Bhatia (1993) continued to work on genre analysis and defined the genre as "a communicative event characterised by a number of communicative purposes that are determined and mutually agreed by the members of the professional and academic communities for which these genres are typical" (p. 13). The defining elements forming the genre are communicative purposes, which set its internal structure. Genres, according to the scientist, are not static phenomena, they are constantly evolving and changing (Bhatia, 2008, p. 162). Even the slightest changes may indicate the formation of sub-genre varieties (Bhatia, 1993, p.13). The scientist introduced a schematic applied model of genre analysis that covers three aspects of discourse analysis: textual, socio-cognitive and critical, according to which discourse can be regarded as text, genre and social practice (Bhatia, 2004, p. 22).

Another representative of this direction Bazerman (1997) considered the genres as "frames" (frameworks) for social action as forms of life, ways of existence which are shaping our thoughts and predetermining communicative actions (pp. 19-26). He introduced the term "genre system" which he explained as the mechanism for determining the sequence of genres interconnected by intertextual relations which can interact with each other under certain circumstances (Bazerman, 1997, pp. 19-26).

The main achievement of the new rhetorical school was the development of a critical genre analysis model (Critical Genre Analysis Approach) and the study of discourse practices of various professional communities.

Miller (1984) described the main characteristics of genres. The scholar defines the genre as "typified rhetorical actions based in recurrent situations" (Miller, 1984, p. 159). Genre plays an important role in the social context of some definite situation, which serves as a social construction that reveals the genre essence. The genre characteristics are the following: 1) recurrent rhetorical situation; 2) social context; 3) particular position between the macro level of culture and micro level of language; 4) rhetorical means for mediating private intentions and social existence, singular with recurrent (Miller 1984, p. 16). Although, in her later work she recognised that the genre definition should be improved as it fails to describe exactly how macrolevel entities, such as culture and genre, contextualise microlevel of discursive acts (Collins, 2012, p. 81). 


\subsection{A sociocultural approach}

In any case, this task was successfully completed by the representative of the Australian school of sociocultural linguistics Freedman (1994) who proved the theory that genres do not just indicate the social roles of the members of discursive interaction. Genres are ceremonials that fix the rules of the game. If players know the rules, they can easily choose necessary genres and act according to the required strategies and tactics (Freedman, 1994, p. 90).

The founder of the Australian systematic functional linguistics Halliday (1978) introduced a sociosemiotic approach to the analysis of social nature of language, which he called "social semiotics" (Halliday, 1978). According to this theory, discourse is as a social language use practice determined by ideology and social knowledge, relationships, and social identity (Fairclough, 2003, p. 20).

According to Halliday, any text can be regarded as a unique semiotic object or event. It means that all the texts include "various ranks of cultural values - as the value systems themselves, and the subsystems that exist as metaphors for them" (Halliday, as cited in Webster, 2015, p. 354). Although the genres themselves were not the focus of Halliday, the researcher noted that linguists should develop a unified methodology for the analysis of texts of different genre varieties, since models constructed ad hoc are not capable of identifying common and distinctive features in the aesthetic and functional layers of these texts (Halliday, as cited in Webster, 2015, p. 315). The scholar believed that genres should be considered within the concept of a register - a set of three components: field, mode, and tenor (participants) of discourse (Halliday, 1978, p. 31). Description of the register can be based on the typical lexical and grammatical traits and situational context.

His follower Martin (1985) offered their vision of the genre. In particular, Martin (1985) noted that the register and genre are sign systems, but in contrast to the language, they form the meanings using the words and structures of another semiotic system - a language that does not use the resources of other systems (p.248). Although this statement is difficult to agree with. Language is a sign system in the background of other systems, which constantly uses the signs of other systems: for example, non-verbal semiotics (Korolyova, 2018). The register in the understanding of the researcher corresponds to the context of the situation, the genre - the context of culture. The genre is "a staged, goal-oriented, and targeted social activity that people engage in as members of their culture" (Martin, 1985, p 250). Directly by Rothery \& Christie (1989) as representatives of this trend consider genres as artefacts of the cultural context.

\subsection{A linguo-didactic approach}

The linguo-didactic approach to the genre analysis developed within the framework of the English for Specific Purposes (ESP) and corpus linguistics is based on the linguistic and rhetorical traditions of two schools - rhetoric and system-functional linguistics, united in the concept of the ESP genre - the teaching of a special language by means of a foreign language for professional or academic purposes. ESP is aimed at students whose first language is not English but who need it for a particular job, activity, or purpose (Luzondo, Ruiz de Mendoza, 2017). ESP includes EAP (English for Academic Purposes), EPP (English for Professional Purposes), EFB (English for Business) (Belcher, 2006), ERPP (English for Research and Publication Purposes) (Flowerdew, 2013). The development of the concept of LSP takes place in two directions: linguistic (functional approach to language learning) and didactic (LSP learning methods). One of the tasks of the genre analysis within this concept is a description of how the text is organised (Hopkins and Dudley-Evans, 1988). Bhatia (1993) distinguishes three levels of linguistic analysis of genres: the lexicalgrammatical organisation of a particular text, the composition of the text, and the structural interpretation of the text (Bhatia, 1993, p. 24).

J. Swales's Creating a Research Space Model mentioned above has contributed a lot to the development of the concept of LSP (Swales \& Feak, 2004). The presented scheme of analysis has become a pattern for the rhetorical structure of genres in different fields.

The lingua-didactic aspect of developing the LSP concept involves teaching academic writing and academic literacy (Lillis \& Carry, 2010). According to Bennett (2009), "the number of works devoted to academic writing is constantly increasing" (p. 44). Corpus-based studies are important as well, as they can provide students with necessary information sufficient to represent the main characteristics of spoken and written academic registers (Biber, 2006, p. 20). Having analysed the available methodological guidance, Bennet concluded that "English academic discourse is a well-structured entity with a number of categorical features, so it is not difficult to reach consensus on the basic principles, methods of design and choice of lexical and grammatical tools for the construction of academic text" (Bennett, 2009, p. 44). The author counted such characteristics of academic discourse as informative value, logic of presentation, clarity of composition, accuracy, evidence, persuasiveness, formalism, technicality, objectivity, simplicity of style (for example, the use of simple sentences in an active voice, commonly used vocabulary) (Bennett, 2009, p. 52). 


\section{Conclusions}

Standard English represented by British English and American English dominates in modern AngloAmerican scientific communication. Moreover, it has become the universal language of science used by different scholars to represent the results of their research in prestigious English-language scientific and scholarly journals indexed in scientometric databases.

The concept of academic discourse is preferable in Anglo-American scientific communication. It is characterised by social context, as it determines social roles and forms of verbally indirect interaction between different discourse communities in the process of data sharing. The following definition and the detailed analysis of this notion has given the grounds for defining it as a hybrid term that is used to distinguish two interrelated types of discourse: instructional-pedagogic discourse aimed at teaching and learning practices in educational establishment and research-oriented discourse relating to research data sharing between different discourse communities. The relationship between these two types of academic discourse is expressed in genre taxonomy.

Academic discourse as an instructional-pedagogical type of discourse comprises such genres, as lecture, seminar, tutorial, interview, students' presentation, and exam. Academic discourse as a research-oriented type of discourse includes such genres, as research report, conference presentation, roundtable discussions, dissertation defence, research article, monograph, dissertation, abstract, and summary.

The research article has become a leading research genre recognised by a distinct rhetorical structure: Introduction, Methods, Results, Discussion and Conclusions.

The representatives of three approaches, namely neo-rhetorical (North American New Rhetoric Studies), sociocultural (Australian systematic functional linguistics) and linguo-didactic approach (English for Specific Purposes - ESP) and corpus linguistics have developed the theoretical backgrounds of genre taxonomy in different fields of knowledge. The neo-rhetorical approach has contributed to genre analysis by providing critical genre analysis approach and investigating discourse practices in different professional communities. The sociocultural approach is based on the semiotic backgrounds of language analysis. The representatives of this approach define the genre as a social and dynamic phenomenon, a cultural artefact.

The lingua-didactic approach of developing the LSP concept focuses on applied genre analysis as well as corpus-based investigations aimed at data collecting and their successful implementation in the teachinglearning process.

\section{References:}

Bazerman, C. (1997). The life of genre, the life in the classroom. In W. Bishop \& H. Ostrum (Eds.), Genre and writing: issues, arguments, alternatives (pp. 19-26). Portsmouth, NH: Heinemann.

Becher, T. and Trowler, P. (2001). Academic Tribes and Territories: intellectual enquiry and the cultures of disciplines (2nd edition). Buckingham: Open University Press/SRHE.

Belcher, D. (2006). English for specific purposes: Teaching to perceived needs and imagined futures in worlds of work, study and everyday life. TESOL Quarterly, 40 (1), 133-156. https://doi.org/10.2307/40264514

Bellés-Fortuño, B. (2010). Spoken Academic Corpora Applied to Language Teaching and Research: Towards a Multimodal Approach (pp. 906-919). London \& New York: Bloomsbury Academic Press.

Bennet, K. (2009). English Academic Style Manuals: A survey. Journal of English for Academic Purposes, 8 (1), $43-54$. https://doi.org/10.1016/j.jeap.2008.12.003

Bhatia, V.K. (Ed.) (1993). Analysing genre: Language use in professional settings. London, New York: Longman.

Bhatia, V.K. (2004). Worlds of Written Discourse: A Genre-based View. Advances in Applied Linguistics. London: Continuum. https://doi.org/10.5040/9781474212038

Bhatia, V.K. (2008). Genre Analysis, ESP and Professional Practice. English for Specific Purposes, 27(2), 161-174. https://doi.org/10.1016/j.esp.2007.07.005

Biber, D. (2006). University language: A Corpus-Based Study of Spoken and Written Registers. Amsterdam/ Philadelphia: John Benjamins publishing Company. https://doi.org/10.1075/scl.23

Brookes, A., \& Grundy, P. (1990). Writing for Study Purposes. A Teacher's Guide to Developing Individual Writing Skills. First edition. Cambridge: Cambridge University Press.

Collins, R. (2012). Genre in Discourse, Discourse in Genre: A New Approach to the Study of Literate Practice. Journal of Literacy Research, 44 (1), 76-96. https://doi.org/10.1177/1086296x11431627

Christie, F., Martin, J. \& Rothery, J. (1989). Genres make meaning: Another reply to Sawyer and Watson. English in Australia, 90, 43-59.

Fairclough, N. (2003). Analysing Discourse: Textual Analysis for Social Research. London, New York: Routledge. https://doi.org/10.4324/9780203697078

Ferris, D. (1998). 'Students' views of academic aural/oral skills: A comparative needs analysis'. TESOL Quarterly, 32, $289-318$. https://doi.org/10.2307/3587585

Flowerdew, J. (2013). English for research and publication purposes. In B. Paltridge, \& S. Starfield (Eds.), The handbook of English for specific purposes (pp. 137-152). Oxford: Whiley and Sons.

Fortanet, I. (2005). Honoris Causa speeches: an approach to structure. Discourse Processes, 7 (1), $31-51$. https://doi.org/10.1177/1461445605048766

Freedman, A. \& Medway, P. (1994). Locating genre studies: Antecedents and prospects. In A. Freedman \& P. Medway (Eds.), Genre and the new rhetoric (pp. 1-20). London: Taylor \& Francis. 
Halliday, M. A. K. (1978). Language as social semiotic: the social interpretation of language and meaning. London: Edward Arnold.

Hopkins, A., \& Dudley-Evans, A. (1988). A Genre-based Investigation of the Discussions Sections in Articles and Dissertation. English for Specific Purposes, 7 (2), 113-122. https://doi.org/10.1016/0889-4906(88)90029-4

Hyland, K. (2004). Disciplinary Discourses. Social Interactions in Academic Writing. Michigan: The University of Michigan. https://doi.org/10.3998/mpub.6719

Hyland K., Diani G. (2009) Introduction: Academic Evaluation and Review Genres. In: Hyland K., Diani G. (eds), Academic Evaluation (pp.2-5). London: Palgrave Macmillan. https://link.springer.com/chapter/10.1057/9780230244290_1

Hyland, K. (2009). Academic Discourse: English in a Global Context. London: Continuum.

Hyland, K. (2011). Academic discourse. In Hyland, K. \& Paltridge, B. (eds.) Continuum Companion to Discourse Analysis (pp.171184). London: Continuum.

Ilchenko, O.M. (2013). Dyskursyvni standarty suchasnoi anhliiskoi movy nauky [Discourse Standards of Contemporary English Language of Science]. Studia Linguistica, 7, 327-337.

Kachru, B. (1992). Introduction: The Other Side of English and the 1990s. In B. B. Kachru (ed.), Models for Non-native Englishes. The Other Tongue: English across Cultures (pp. 48-74). Urbana \& Chicago: University of Illinois Press.

Kapranov, Y. V. (2018). Hypothetical Versions on Antropogenesis Localization of the First Populations of the Homo. Logos, 94, 149-158. https://doi.org/10.24101/logos.2018.15

Korolyova, A. V. (2018). Reconstruction of Early Migration Routes of Homo Populations. Logos, 94, 159-166. https://doi.org/10.24101/logos.2018.16

Korneiko, I.V., Petrova, O.B., \& Popova, N.O. (2014). Teoriia zhanru: teoretychni ta prykladni aspekty [Genre theory: theoretical and applied aspects]. Kharkiv: "Drukarnia Madryd".

Lillis, T. \& Curry, M. J. (2010). Academic Writing in a Global Context: The Politics and Practices of Publishing in English. London and New York: Routledge.

Luzondo, A. \& Ruiz de Mendoza, F. (2017). Argument-structure and implicational constructions in a knowledge base. Onomazein, 35, 25-48. http://doi.org/10.7764/onomazein.35.04

Martin, J.R. (1985). Process and Text: Two Aspects of Semiosis. In J. D. Benson and W. S. Greaves (Eds.), Systemic Perspectives on Discourse. Vol. 1: Selected Theoretical Papers from the 9th International Systemic Workshop (pp.248-274). Amsterdam: John Benjamins.

Miller, C. R. (1984). Genre as Social Action. Quarterly Journal of Speech, 70 (2), 151-167. https://doi.org/10.1080/00335638409383686

Perez, L. C. A. (2001). Designing new genre identities in scientific and technical discourse: cognitive, social and pedagogical implications. Journal of English studies, 3(2), 251-263. https://doi.org/10.18172/jes.81

Swales, J. (1990). Genre analysis: English in Academic and Research Settings. Cambridge: Cambridge University Press.

Swales, J \& Feak C. (2004). Academic Writing for Graduate Students: Essential Skills and Tasks. 2nd edition. Ann Arbor, MI: University of Michigan Press

Swales, J. (2004). Research genres: Explorations and Applications. Cambridge: Cambridge University Press. https://doi.org/10.1017/cbo9781139524827

Webster, J. (2015). The Bloomsbury Companion to M.A.K. Halliday. London \& New York: Bloomsbury Academic Press. https://doi.org/10.5040/9781472541888

White, P.R.R.\& Motoki S. (2006). Dialogistic Positions and Anticipated Audiences - a Framework for Stylistic Comparisons. In. Karin Aijmer, Anne-Marie Simon-Vandenbergen (Eds.), Pragmatic Markers in Contrast (pp. 189-214). Amsterdam: Elsevier.

Received: May 21, 2018

Accepted: June 15, 2018 